\title{
MAXIMS VIOLATION ON “NIGHT AT THE MUSEUM” MOVIE
}

\author{
Andy ${ }^{1}$ \\ Universitas Putera Batam (UPB), Batam, Indonesia \\ e-mail: pb161210024@upbatam.ac.id ${ }^{1}$ \\ Ambalegin ${ }^{2}$ \\ Universitas Putera Batam (UPB), Batam, Indonesia \\ abhi140475@gmail.com²
}

\begin{abstract}
This research was created based on concerning the importance of efficient language use. The language use is called efficient if the message is clear, unambiguous and understandable both speaker and hearer. Cooperative principles theorized by Grice (1975) explained the way people use the language well and efficiently. There are four maxims in order to have achieve connection during conversation which are 1) maxim of quality, 2) maxim of quantity, 3) maxim of relation, and 4) maxim of manner. In fact, there are several maxim violations happened in human life especially figured in the movie. The maxim violations may cause misunderstanding while the conversation is going on. This investigated the maxim violations that existed in the movie 'Night at the Museum'. This research applied descriptive qualitative method with pragmatics identity analysis. The findings showed that all kind of maxims were violated with maxim of manner and quantity as the dominant violated maxims.
\end{abstract}

Keywords: conversation, cooperative principle, maxim violation

\section{INTRODUCTION}

Language roles as a bridge that connects two or more people. Communication is the way how language is used. It is unique where each other try to deliver their idea and its meaning which they understand together (Mubarak, 2019). In other words, the language said must be simple and efficient in order to get a connection among speakers. It is used as a media to communicate in human society. Not only society, but also language is used to illustrate a literary works. Movie is one of popular media to reflect human society. It is usually figured in form of actions and conversations. Furthermore, those elements help connect an event to another. The better the elements created, the smoother the movie is. Both action and conversation were designed to play essential part of movie story. Conversation happened between speaker and hearer. Speakers had to understand the meaning of utterances they said and formed it in simple way in order to make the hearer understand of what had been talked (Ambalegin \& Suryani, 2018). So that misunderstanding could be minimalized meanwhile what they were talking about was connected each other. One of related phenomena is shown in the below conversation.

$$
\begin{array}{ll}
\text { Larry } & \text { : "Hey, Mike!" } \\
\text { Mike } & \text { : "Hey, Larry. How you } \\
\text { doing?" } & \\
\text { Larry } & \text { : "Have you seen Nicky?" } \\
\text { Mike } & \text { :"I'm pretty sure he went } \\
& \text { with Erica. It was half day } \\
& \text { today. Parent Career } \\
& \text { Day." }
\end{array}
$$

This quoted conversation existed in the beginning of Night at the Museum movie at the minute of $03: 43$. There was no any mistakes happened in the form of structure, however, it could be seen that the way how Larry and Mike responded 
each other did not connected. By looking more specific at the interrogative sentence construction, the answer supposed to be connected to the question. Logically, if somebody asked about the condition as well as greeting, the response the hearer would get was related to the condition by saying like "I'm good", "Not bad", and many more. In fact, what the actor responded was out of what had been asked. Grice (as cited in Yule, 2010) called this phenomena as the maxim violation that might cause uncooperative principle during the conversation. It was able to break the connection or relation in the conversation if one of speaker or hearer was not comfortable of unclear response. There was no more connection between the previous question with the answer. Furthermore, in the third utterance, Larry asked whether Mike had seen Nicky. In other side, Mike gave the detail information about all he suspected rather than simply answer "yes" or "no" since it was only closed question. Larry might not need the further information. In simply word, there were some maxim violation types that caused uncooperative principles which affected to effectiveness of the conversation.

Based on explanation above, cooperative principles were made to create a well-connected conversation. By following the use of cooperative principles, people were expected to get the meaning and prevent the misunderstanding. However, on the Night at the Museum movie, the actors spoke uncooperatively. As the result, it caused unclear meaning and sometimes ambiguous to the other actors who played in the movie. Thus, this research found out the types of maxims violation causing uncooperative principles.

\section{MAXIMS VIOLATION}

Several studies related to this research have been done around the world. Ulliyadhi \& Raharja (2019) analyzed maxims violated by Dodit Mulyanto's in Stand Up Comedy Indonesia show. They used qualitative method and came to the result that Dodit violated all maxims of cooperative principles. The maxims violation done in order to express jokes to the audience. Another researcher came from United Kingdom, Fukumura \& van Gompel (2017) who conducted the research about how Gricean maxims violation affected reading. The research method used was qualitative since the discussion was explained by using words. It came to result that the violation of Gricean maxims might cause problem with referring expressions that leaded to the ambiguous. Fahmi in 2019 also did another research regarding to the maxims violation found in daily conversation. He applied descriptive qualitative method. In addition, in order to get the data, he did the observation and interview. The analysis result showed that all maxims were violated. Furthermore, social distance and cultural factors became the reasons of violating those maxims. Besides, Rahmi, Refnaldi, \& Wahyuni (2018) also conducted similar research with Talkshow as the object. They used qualitative method and finished with the result of all maxims were violated. Quantity maxim was the most dominant maxim to be violated since on the talkshow, the speakers had to take attention and sympathy from the audience and viewers. Finally, Barry, Khosravizadeh, \& Sadehvandi (2011) also did the research focusing on maxim of quantity violation. They took a comedy movie titled "Dinner for Schmucks" as the object. Not different with the previous ones, this research also applied qualitative method. They 
concluded that the main characters of the movie, Tim and Barry had different frequency doing quantity maxim violation. Barry was talkative so that he broke the maxims often meanwhile Tim was not. In this paper, it can be concluded that the researcher did the different research especially in the research object. The researcher took the data from Night at the Museum movie and analyzed all the characters' utterances that related to maxims violation.

The most interesting case is that of flouting or exploitation of a maxim: essentially, flouting is violating a maxim that is salvaged by the fact that the speaker is fulfilling another maxim (Attardo, 1993). He continued if two students meet before class in the outside of the classroom and one asks the other, "What time is it?" then answer is, "The bell has not rung yet", the answer categorized into maxim of relevance violation. However, by assuming that the answer does in fact fulfill another maxim (quantity) people can reconstruct meaning that the student informs that the class has not started yet since the bell has not rung. Grice (as cited in Paltridge, 2012) described cooperative principles on four sub-principles, or maxims. Those maxims have the different ways to be violated. Grice (as cited in Fukumura \& van Gompel, 2017)stated that violations of the maxims result in an inference or conversational implicature, whereby the literal meaning of the utterance is reconciled with the assumption that language producers are obliging the maxims. Thus, people who modify the conversation by doing maxims violation indirectly create a new structure of meaning and comprehension through the language used. Below are the explanation of maxims of quality, quantity, relation, manner and their violations.

\subsection{Maxim of Quality}

In this maxim, $\mathrm{He}$ explained that an utterance should be said truly based on what happening in the real life. According to Grice (1975), people had to speak what they believe true and in fact it could happen. If somebody told that there was a unicorn in the city, the sentence made had already broken the quality maxim. All discussion about myths, fairy tale, and the like could be considered as quality maxim violation as long as it could not be proved. Simply, if the utterance was not based on the fact of what happening, it could be considered as the violation of quality maxim as shown below.

$$
\begin{aligned}
& \text { A : "What are you doing now?" } \\
& \text { B : "I am eating." } \\
& \text { A : "Are you hungry?" } \\
& \text { B : "No, I am not." }
\end{aligned}
$$

The example above showed the role of maxim of quality. A asked about what B was doing. B answered based on the fact that he was eating. It was the true condition of what happening to $\mathrm{B}$ and he called it as a cooperative principle. However, in the next question and response when A asked, "Are you hungry?" B answered in a condition in his believe was false. He had to be hungry so he took the foods. In this case, B also broke the maxim of quality. Speaker and listener could be considered violating the maxim of quality when they are not truthful (Rahmi et al., 2018). 2.2 Maxim of Quantity

The maxim required the speakers to speak properly of what was needed to be answered. Furthermore, the answer should be informative; answer the question and not to give more explanation. If the answer was clear enough to answer the question, therefore no need additional information that might cause uncooperative principle. The adding information which was said to reply other's question should be 
considered as the violation of quantity maxim. Sometimes in the interview or talk show, the speakers violate the maxim of quantity to gain attention and give more explanation. Impliedly, the quantity maxim violation is usually described as positive effect. To make it easy to understand, look at the example below.

A : "How many people in your family?"

B : "There are five people."

A : "Do you have brother?"

B : "Yes, I do. I have 2 siblings and

I am the youngest."

The example above explained how the quantity maxim works. According to Grice (1975), the first question and answer were cooperative principle. They followed the rule of quantity maxim. B had already answered what was required in the A's question. In other side, in the second question and answer, B did not follow the quantity maxim rule. $\mathrm{He}$ added more information regarding to the question. It was cooperative if $\mathrm{B}$ answered with "Yes, I do." The speaker and hearer violated the maxim of quantity when they were not

informative as required (Rahmi et al., 2018).

\subsection{Maxim of Relation}

The point of this maxim is what you are saying must be related to the previous statement or question. Grice (1975) said that people should be relevant in the communication. The speakers had not to say something outside the topic or what was not having the correlation of what being discussed. This maxim was a bridge that brought the interaction connected one another. In other side, the violation of relevance maxim used to bring hidden meaning to the listener. The speaker said something which out of the topic, however, they had invisible meaning to be discovered. Furthermore, the following dialogs could make the explanation easy to be understood.

A : "What do you eat, John?"

J : "Oh, it is spaghetti."

A : "It looks delicious. Could I taste some?"

$\mathrm{J}$ : "Your shirt is really nice."

It could be seen that the conversation held was categorized as both cooperative and uncooperative principles. When A asked of what kind of food that $\mathbf{J}$ ate, $\mathbf{J}$ replied with proper answer which was spaghetti. It was clearly described as a cooperative principle. Nevertheless, when A asked for tasting the spaghetti, John gave his other respond which was not relevant; out of the topic. The utterance "You shirt is really nice" was not relevant and did not response previous question well. Although it was not a proper answer, it could have implied meaning of refusing A to taste the food since he did not answer of what being asked. The actors violated maxim of manner when they were become irrelevance (Rahmi et al., 2018).

2.4 Maxim of Manner

Grice (as cited in Paltridge, 2012) argued that the utterance said should be clear, unambiguous, and brief in order to achieve cooperative principle in interaction. It was called maxim of manner. The opposite of clear expression; could be in form of ambiguous and unclear statement would be considered as the violation of manner maxim. To avoid misunderstanding and ambiguous meaning, the listener had to have relation, background knowledge, or little introduction with the topic discussed. Otherwise, the conversation will not lead both speaker and listener to connect each other. To make it simply, it is given the example below to improve understanding of manner maxim:

A : "What do you think of Cindy?"

D : "She is a beautiful girl." 
A : "How about her characteristics?"

D : "She is like Ria."

As the previous examples, this example was also given with two sides of principle which were cooperative and uncooperative. The expression of first discussion was a cooperative principle. The response gave a simple comment about Cindy and everybody knows what the word "beautiful" looks like. It was not an ambiguous response too. In different side, the second reaction expressed a violation of manner maxim. By saying "She is like Ria", D was the only one who knew "Ria" and it was very unclear expression. If A also knew Ria, the interaction would be connected otherwise A would get misunderstanding too. In simply words, not everyone knows who Ria is and directly knows what $\mathrm{D}$ means. The speaker and hearer violated maxim of manner when they were become ambiguous (Rahmi et al., 2018). To sum up, those were what Grice (1975) explained about four maxims as the guidance of effective communication. In contrast, although cooperative principle leaded to proceed the conversation smoothly, people still broke these maxims for several purposes (Barry et al., 2011). Thus, the researcher would show some data to be analyzed as maxims violation.

\section{RESEARCH METHOD}

This research was done by describing the data using words and sentences. Therefore it was designed as a descriptive qualitative research proposed by Sudaryanto (2015). The researchers observed the data through watching Night at the Museum directed by Levy (2006). Then there were several data which related to the topic then they were taken as the object of the research. The researchers did not act as the participants or the actors on this movie. In other words, this research was non participatory technique. While analyzing the data, the researchers used pragmatics identity method. Pragmatics study as the roof of the analysis. Lastly, utterances existed in the movie were analyzed in the pragmatics study supported by the cooperative principles theory of Grice (1975). Every single violation of each maxim would be considered as the form of maxims violation.

\section{RESULT AND DISCUSSION}

There were 13 data found on "Night at the Museum" movie to show maxims violation. There were 3 data indicated relation maxim violation. Next, there were only 2 data supported quality maxim violation. Furthermore, there were 4 data showed manner maxim violation. Finally, 4 data also indicated violation of quantity maxim. In fact, there were 4 kinds of maxim violations existed on Night at the Museum. The data and analysis results are shown below.

Data 1

Larry : "Hey, do you think Nick would like Queens?"

Erica : "Oh no, Larry. You didn't get evicted again, did you?" (00:05:07)

Data 1 showed that relation maxim was being violated. Erica intentionally broke the cooperative principal. There was no relation between closed question about Queens and Erica's response. She responded something that was not related to the question. It caused misunderstanding for those who had lack of background knowledge about Larry's problem.

Data 2

Larry : "I didn't...get evicted. I didn't get evicted, no. I mean, I didn't. No, I didn't get evicted yet. It's like-" 
(00:05:14)

In the above data, it showed a violation of quality maxim. Larry did not say what he believed true. In other word, he was doubt to say what just happened. There was no specific answer whether he got evicted or not. It seemed that the actor tried to lie by expressing the utterance doubtfully. Thus, Larry's utterance did not meet requirement of cooperative principles and considered as a quality maxim violation.

Data 3

Larry : "I'm trying to figure things out right now, okay?"

Erica : “...You know...I don't think that Nicky should stay with you."

Larry : "What?"

Erica : "Just until you get really settled."

(00:05:34)

It was positive to say that Erica broke maxim of quantity. She argued angrily and did not answer Larry's statement in right portion. Instead of saying "Okay", she added her disagreement to let Nicky stayed with Larry. The adding comment by Erica signed that she answered more than what was needed. According to Grice's theory, it was considered as violation of quantity maxim.

Data 4

Larry : "That's cool. So you wanna dress up in a monkey suit and tie every day? Like an automaton robot? Trust me, you can't play hockey in a cubicle. Kind of awkward."

(00:06:56)

Utterance above showed an irrelevant argument. The most important requirement of relation maxim is be relevant so that it can be included into cooperative principles. Nevertheless, there was no relevance between words used. There were monkey suit, automaton robot, and playing hockey in a small room which are not related. Thus, it showed that Larry broke relation maxim. Besides, he also broke quality manner by saying, "That's cool". However, it really was not cool as could be looked at last utterance, "Kind of awkward".

Data 5

Nick : "Well, he's got a pretty big office."

Larry : "That's not the point. Come on, you love hockey."

Nick : "I still like it, but bond trading's my fallback."

(00:07:07)

Fifth data showed a violation that happened to relation maxim. Nick said, "Well, he's got a pretty big office" which then explained by Larry that it was not their point of discussion. Nick had said what was not related to the conversation. This kind of violation might cause ineffective conversation which made the speaker and hearer were not connected. Furthermore, it is usually used to get some reasons to move out from the topic as Nick did.

Data 6

Rebecca : "Let me point you in the right direction."

Larry : "Great. Teddy

Roosevelt, right?"

Rebecca : "Yes, a great visionary."

Larry : "Yes, definitely. He was our 4th president, right?

Rebecca : "Twenty-sixth."

Larry : "Twenty-sixth."

(00:11:04)

When a response is more detail than it is required, it can be identified as quantity maxim violation. The data showed another violation of quantity maxim. Rebecca broke it by adding more details about Teddy Roosevelt who was a great visionary. Impliedly, Rebecca mean to 
give more explanation and background about who Teddy Roosevelt was. However, Grice (1975) considered it as quantity maxim violation.

Data 7

Cecil : "Gus, this is Larry Daley, the kid who wants to be the new night guard."

(00:13:03)

Cecil on "Night at the Museum" movie violated quality maxim. He knew that Larry was an adult man by looking at the appearance. He did not say to Gus what he believed true, however, he said Larry was a kid. In fact, Cecil said it oppositely. Moreover, there was not a kid who kept the museum all night as night guard. Thus, the utterance "the kid who wants to be the new night guard" was a sign of quality maxim violation done by Cecil.

Data 8

Larry : "Night guard? No, the lady at the agency said this was a museum position."

Cecil : "Most important position in the museum, Larry."

Gus : "He looks like a weirdie."

(00:13:04)

Eighth data explained that Larry violated the maxim of manner. When he said "No, the lady at the agency said this was a museum position," Cecil and other night guards were wondering who she was. Those words were not clearly made so that Cecil and others misunderstood. To make it efficient, Larry supposed to introduce the person he was referring.

Data 9

Cecil : "Larry, do them in order, do them all and do them quick. And the most important thing of all to remember: Don't let anything in or out." Larry : "Out?"
Cecil : "Good luck, son."

(00:18:07)

At the minute 18:07, Cecil violated maxim of manner. In the words, "Don't let anything in or out" was ambiguous and unclear. In other side, Cecil did not explain detail about his statement. That's why it made Larry became confused. Larry had to think who would go in and out in the museum at midnight. In fact, Cecil impliedly referred his utterance to all the statue which became alive in the night.

Data 10

Easter : "Dum-dum."
Larry : "Yes?"
Easter : "You give me gum-
gum."

Larry : "I give you gum-gum?"

Easter : "You new dum-dum. You give me gum-gum."

Larry : "Okay, you know what? I have no gum-gum. Sorry. And my name isn't dum-dum, my name's Larry."

(00:24:50)

It could be seen in the data above that Easter violated the maxim of manner. It talked about strange words which made Larry did not understand. The maxim violation caused Larry did not know what Easter called and wanted from him. Larry was wondering of who was dumdum and what gum-gum mean.

Data 11

Larry : "Hey, blondie?"

Jedediah : "Name's Jedediah."

Larry : "All right, Jedediah.

Stop the train, please."

Jedediah : "That's a big no-can-do, Cracker Jack."

Larry : "What's going on here, huh?"

Jedediah : "Somebody's gotta pay."

Larry : "Pay for what?" 
Jedediah : "I don't know. Just pay. Now, stop whining and just take it like a man."

(00:33:55)

Jedediah violated both manner and quality maxim as per shown as eleventh data. When Larry asked what's happening, Jedediah said, "Somebody's gotta pay." Jedediah responded it incompletely and made Larry asked for more information. In addition, Jedediah answered it with no relation to the Larry's question. No correlation between question and respond which caused a confusion was an effect of manner maxim violation. Furthermore, Jedediah said what he believed false that somebody's gotta pay, but in fact he did not know pay for what. In simple words, Jedediah also broke maxim of quality by accusing without any valuable reasons.

Data 12

Nick : "What's going on?"

Larry : "If I told you, you'd

think I'm crazy. I'm gonna show you."

Nick : "What?"

Larry : "You'll see in about 20

seconds. Okay, you like Tyrannosaurus Rex?"

Nick : "Yeah."

Larry : "Yeah? Well, I call him Rexy. And he's about to come to life, Nicholas, in...five, four, three, two...."

Nick : "Dad?"

Larry : "Hang on a sec. Say hello to Rexy!"

Nick : "Dad, are you okay?" $(01: 13: 18)$

The last data was what cited above. Manner maxim was violated by Larry. Larry spoke unclearly to explain what happening to his son, Nick. When Nick was confused of what his dad did, he began to ask and his father respond was not clear. However, Larry kept answering without specific answer. In simply words, it could be seen in the conversation, Nick kept asking of what happening and all his dad uttered could not meet requirement of what had to be answered.

\section{$5 . \quad$ CONCLUSION SUGGESTION}

Grice's maxims influenced the effectiveness of conversation on "Night at the Museum" movie. It was found that all the Grice's maxims had been violated by the actors. The violations occurred to three maxims of quality, two maxims of quantity, three maxims of relation, and five maxims of manner. The most frequent violated maxims was maxim of manner. The less violated maxims was maxim of quantity. All violated maxims were created in order to design an interesting plot to the movie story. It is a fact that the movie was alive with the combination of maxims violation. Although there were several violated maxims, the plot of the movie was enjoyed and understood by the viewers.

By looking at the research findings and conclusion, it is very important to know maxims violation. It is useful for speakers and hearers to avoid misunderstanding while conveying some information. By knowing the use of cooperative principle, speakers are able to minimalize the violation so that information spoken is understandable. In other side, the hearer will be able to identify the meaning if there are some violation occurred.

\section{REFERENCES}

Ambalegin, \& Suryani, M. S. (2018). Morphosyntactic analysis of inconsistent formation of English words , phrases, and sentences. Advances in Social Science, Education and Humanities Research, 200(Aisteel), 472-478. 
https://doi.org/https://doi.org/10. 2991/aisteel-18.2018.102

Attardo, S. (1993). Violation of conversational maxims and cooperation: The case of jokes. Journal of Pragmatics, 19, 537558.

Barry, M. C., Khosravizadeh, P., \& Sadehvandi, N. (2011). Some instances of violation and flouting of the maxim of quantity by the main characters ( Barry \& Tim ) in Dinner for Schmucks. 2011 International Conference on Languages, Literature and Linguistics, 122-127. Singapore: IACSIT Press.

Fahmi, R. (2019). An analysis of Grice's maxims violation in daily conversation. Journal of Languages and Language Teaching, 4(2), 91. https://doi.org/10.33394/jollt.v4i2.3 25

Fukumura, K., \& van Gompel, R. P. G. (2017). How do violations of Gricean maxims affect reading? Journal of Memory and Language, 95, $1-18$. https://doi.org/10.1016/j.jml.2017.0 1.008

Grice, H. P. (1975). Logic and conversation. New York: Academic Press.

Levy, S. A. (2006). Night at the museum. United States: 20th Century Fox.

Mubarak, Z. H. (2019). The analysis of repetititon as part of lexical cohesion in talk shows. Jurnal Basis, 6(1), 81-94. https://doi.org/10.33884/basisupb.v $6 \mathrm{i} 1$

Paltridge, B. (2012). Discourse analysis an introduction (2nd ed). Retrieved from

http://linguistics.paltridge2e.continu umbooks.com

Rahmi, S. S., Refnaldi, \& Wahyuni, D. (2018). The violation of conversational maxims found in political conversation at Rosi Talkshow. E-Journal of English Language and Literature, 7(1), 177-183.

Sudaryanto. (2015). Metode dan aneka teknik analisis bahasa. Yogyakarta: Sanata Dharma University Press.

Ulliyadhi, A., \& Raharja, S. (2019). Maxim of cooperative principle violation by Dodit Mulyanto in Stand-up Comedy Indonesia Season 4. Journal of Pragmatics Research, 1(1), 62-77. https://doi.org/http://dx.doi.org/10.1 836/jopr.v1i1.62-77

Yule, G. (2010). The study of language (4th ed). New York: Cambridge University Press. 
